\title{
The Relationship Between Knowledge, Attitude and Perception With Behavior In Consuming Herbal Medicine in Singaraja City
}

\author{
Nyoman Sri Ariantini*, Eka Lutfiatus Solehah \\ Rana Wijaya High school of health sciences Singaraja, Indonesia \\ Correspondingauthor:nariantini@gmail.com
}

\begin{abstract}
Background: The emergence of various diseases such as the COVID-19 pandemic is now causing the public to seek various treatments and to strengthen the body's immune system. The transmission of the virus through local transmission causes the number of COVID-19 cases to continue to grow. Therefore, prevention efforts must be made, namely the breaking of the chain of transmission with self-isolation, early detection, and basic protection. The basic excretion referred to by other children washing hands regularly with soap or using hand sanitaizer, maintaining distance, and consuming healthy foods to improve the immune system.

Purpose: This study aimed to find out the relationship between knowledge, attitude and perception with behavior in consuming herbal medicine.

Methods: The design of this study is observationally descriptive with a crossectional approach. Singaraja city has an area of $27.98 \mathrm{~km} 2$, and its population of 80,500 people is used the type of probability sampling technique simple random sampling. The sample is calculated by the formula obtained as many as 100 respondents. The data was collected with questionnaire instruments and analyzed with chis square tests.

Results: The results showed a value of $\rho$ for knowledge, attitude and perception $<\alpha$ then this shows a relationship between knowledge, attitude and perception with behavior in consuming herbal medicine.

Conclusion: The community still gives a positive response to traditional medicine through herbal medicine. This happens because the public already knows enough about the benefits of consuming herbal medicine that can maintain and increase immunity especially in the pandemic period this is needed.
\end{abstract}

Keywords: Knowledge, Attitude, Perception, Behaviour, Herbal Medicine. 
Journal Of Nursing Practice

http://thejnp.org

ISSN: 2614-3488 (print); 2614-3496 (online)

Vol.5 No.1. October 2021. Page.94-102

\section{BACKGROUND}

The emergence of various diseases such as the COVID-19 pandemic is now causing the public to seek various treatments and to strengthen the body's immune system. The transmission of the virus through local transmission causes the number of COVID-19 cases to continue to grow. Bali Provincial Health Office data said that the addition of positive cases increased every day where data as of October 13, 2020 the number of postive cases in Bali amounted to 10304 people and Buleleng regency with the number of positive cases amounted to 965 people. 6 Therefore, prevention efforts must be made, namely the breaking of the chain of transmission with self-isolation, early detection, and basic protection. The basic protectors in question include washing hands regularly with soap or using hand sanitaizer, maintaining distance, and consuming healthy foods to improve the immune system.

World Health Organization (WHO, 2003), countries in Africa, Asia and Latin America use herbal remedies as a complement to primary treatment. In Africa as many as $80 \%$ of the population uses herbal medicine for primary medicine. Research in the United States shows that the use of herbal remedies increased from 3\% in 1990 to $12 \%$ in 1997 , and 19\% in 2002 (Pinzon, 2007). Currently the use of CAM (Complementary and Alternative Madacine) in the United States reaches $40 \%$ and in the United Kingdom reaches $20 \%{ }^{4}$.

WHO recommends the use of alternative medicines including herbs in the maintenance of public health, prevention and treatment of diseases, especially for chronic diseases, degenerative diseases and cancers. WHO also supports efforts to improve the safety and efficacy of traditional medicine.

Herbal medicine is one of the cultural heritage of the Indonesian nation that has been used down and down. The results of Basic Health Research (Riskesdas) in 2018 on the use of herbal medicine by the people of Indonesia, found that $59.12 \%$ of the public still consume herbal medicine and more than $95.6 \%$ of them recognize the benefits of herbal medicine for health. According to Siswanto (2012) herbal medicine is a traditional drink native to Indonesia that has medicinal properties. Herbs are served in powder, steeping, pills or liquids. According to the regulation of the Minister of Health (PERMENKES) in 2010 herbal medicine is a traditional Indonesian medicine ${ }^{3}$.

According to Puspitasari (2020) some herbal plants that have been studied and proven to be able to increase immunity include meniran (Phylanthus niruri), java chili (piper longum), lime (Citrus aurantifolia), turmeric (Curcuma longa). In addition, there are herbal processed as herbal medicine that is drunk directly, including rice kencur, turmeric asem, temulawak and traditional herbal drinks5. The behavior of the consumption of herbal medicine as a booster of the immune system is inseparable from the level of knowledge, attitude and perception of a person in the consumption of herbal medicine in the community. A person's level of knowledge will have an impact on his level of trust in something. A person's level of trust will also affect his attitude. Knowledge and attitude factors have a major influence on the formation of perceptions in the community and affect the health status of individuals and communities and play an important role in the success of disease management programs and prevention of transmission including COVID-19 disease. The hope is that with the increasing consumption of herbal medicine in the community, it will play a role in improving public health status, one of which can maintain or improve the immune system among the public in the midst of the COVID-19 pandemic..

\section{METHODS}

The level of knowledge, attitudes, and perceptions of urban communities towards the behavior of herbal consumption during the COVID-19 pandemic are the issue that learn 


\section{Journal Of Nursing Practice}

http://thejnp.org

ISSN: 2614-3488 (print); 2614-3496 (online)

Vol.5 No.1. October 2021. Page.94-102

in this research. Design is a type of descriptive research using analytical research design and cross-sectional design (cut latitude). The design of this study was chosen to examine an event at the same time (at the same time). Independent variables are the level of knowledge, attitudes and perceptions of urban communities, while dependent variables are the behavior of herbal consumption during the COVID-19 pandemic. The sampling technique in this study will use probability sampling, namely Simple Random Sampling, which is sampling in populations that are done randomly regardless of the strata in the population. With an area of singaraja city of $27.98 \mathrm{~km} 2$, and its population amounted to 80,500 people. Using the formula slovin, the number of samples in this study was obtained amounting to 100 people. The inclusion criteria are people domiciled in singaraja city, accustomed to consuming herbal medicine during the covid-19 pandemic, willing to be respondents and aged 17-60 years, have an internet-connected mobile phone so that they can access googleform online questionnaire, While the exclusion criteria are respondents who are incomplete to fill out online questionnaires or system errors such as duplicated data. The research data was obtained from the collection of questionnaires online with the googleform application that was shared with respondents through a link on the whatsapp application. The data is then processed and analyzed with univariate SPSS applications with frequency distribution and bivariate with Chi Square at a confidence level of $95 \%$.

\section{RESULTS AND DISCUSSION}

The result of this study that's can be explained below:

1. General Data

Table 1 Distribution of respondent frequency based on general data in Singaraja City

\begin{tabular}{llcc}
\hline \multicolumn{1}{c}{ No } & \multicolumn{1}{c}{ General Data } & Frequention & \% \\
\hline Age & & & \\
\hline $\mathbf{1}$ & $\leq 20$ Years & 24 & 24 \\
\hline $\mathbf{2}$ & $21-35$ Years & 70 & 70 \\
\hline $\mathbf{3}$ & $>35$ Years & 6 & 6 \\
\hline
\end{tabular}

\begin{tabular}{llll}
\hline Gender & & & \\
\hline $\mathbf{1}$ & Man & 37 & 37 \\
\hline $\mathbf{2}$ & Woman & 63 & 63 \\
\hline
\end{tabular}

\begin{tabular}{llcc}
\hline \multicolumn{2}{l}{ Education } & & \\
\hline $\mathbf{1}$ & Senior High School & 50 & 50 \\
$\mathbf{2}$ & Bachelor & 45 & 45 \\
\hline $\mathbf{3}$ & Magister & 5 & 5 \\
\hline
\end{tabular}

\begin{tabular}{llll}
\hline \multicolumn{2}{l}{ Domicile } & & \\
$\mathbf{1}$ & In the city of Singaraja & 61 & 61 \\
\hline $\mathbf{2}$ & Out the city of Singaraja & 39 & 39 \\
\hline
\end{tabular}

\begin{tabular}{llll}
\hline Salary & & & \\
\hline $\mathbf{1}$ & $\leq$ Rp. 2000.000 & 65 & 65 \\
\hline $\mathbf{2}$ & Rp. $2.000 .001-R p .3 .000 .000$ & 24 & 24 \\
\hline $\mathbf{3}$ & $>$ Rp. 3.000 .000 & 11 & 11 \\
\hline
\end{tabular}




\begin{tabular}{|lccc}
\hline \multicolumn{2}{l}{ Consumption of herbs } \\
\hline $\mathbf{1}$ & Routine & 0 & 0 \\
\hline $\mathbf{2}$ & Not & 100 & 100 \\
\hline Total & & 100 & 100 \\
\hline
\end{tabular}

Based on table 1 shows data that based on the age of respondents obtained data mostly aged 21-35 years as many as 70 respondents (70\%). Based on gender, most of the female sex data was obtained as many as 63 respondents $(63 \%)$. Based on education obtained data half have a high school education background as many as 50 respondents $(50 \%)$. Based on the place of domicile obtained data mostly domiciled in singaraja city as many as 61 respondents $(61 \%)$. Based on income obtained data mostly have income $<$ Rp. 2,000,000 as many as 65 respondents (65\%). And based on the consumption of herbal medicine obtained data all respondents are not routine in consuming herbal medicine.

\section{Special Data}

Table 2 Distribution of respondents' frequency based on special data in Singaraja City

\begin{tabular}{|c|c|c|c|}
\hline No & Special Data & Frequention & $\%$ \\
\hline \multicolumn{4}{|c|}{ Knowledge } \\
\hline 1 & Good & 39 & 39 \\
\hline 2 & Enough & 51 & 51 \\
\hline 3 & Less & 10 & 10 \\
\hline
\end{tabular}

\begin{tabular}{llll}
\hline \multicolumn{2}{l}{ Attitude } & & \\
\hline $\mathbf{1}$ & Negative & 45 & 45 \\
\hline $\mathbf{2}$ & Positive & 55 & 55 \\
\hline
\end{tabular}

\begin{tabular}{llll}
\hline \multicolumn{2}{l}{ Perception } \\
\hline $\mathbf{1}$ & Negative & 41 & 41 \\
\hline $\mathbf{2}$ & Positive & 59 & 59 \\
\hline
\end{tabular}

\begin{tabular}{llcc}
\hline \multicolumn{2}{l}{ Behaviour } & & \\
\hline $\mathbf{1}$ & Consumption & 53 & 53 \\
\hline $\mathbf{2}$ & Not & 47 & 47 \\
\hline Total & & 100 & 100 \\
\hline
\end{tabular}

Based on table 2 shows data that based on knowledge about herbal medicine obtained data most respondents have enough knowledge as much as 51 respondents $(51 \%)$. Based on the attitude obtained data most respondents showed a positive attitude as many as 55 respondents (55\%). Based on the perception of herbal medicine obtained data mostly have a potitive perception of herbal medicine as many as 59 respondents $(59 \%)$. Based on behavior in consuming herbal medicine obtained data mostly consuming the herbal medicine as many as 53 respondents $(53 \%)$. 


\section{Journal Of Nursing Practice}

http://thejnp.org

ISSN: 2614-3488 (print); 2614-3496 (online)

Vol.5 No.1. October 2021. Page.94-102

\section{Result of Byvariat Analysis}

1) Bivariate analysis between knowledge and behavior

Table 3. Cross-tabulation between knowledge variables and herbal consumption behavior in Singaraja City

\begin{tabular}{|c|c|c|c|c|c|c|}
\hline \multirow{3}{*}{$\begin{array}{c}\text { Knowledg } \\
\text { e }\end{array}$} & \multicolumn{4}{|c|}{ Consumtion Behaviour } & \multicolumn{2}{|c|}{ Amount } \\
\hline & \multicolumn{2}{|c|}{ Yes } & \multicolumn{2}{|c|}{ Not } & & \\
\hline & $f$ & $\%$ & $\mathrm{~F}$ & $\%$ & $\mathrm{f}$ & $\%$ \\
\hline Good & 28 & 71,8 & 11 & 28.2 & 39 & 100 \\
\hline Enough & 24 & 47,1 & 27 & 52.9 & 51 & 100 \\
\hline Less & 1 & 10 & 9 & 90 & 10 & 100 \\
\hline Amount & 53 & 53 & 47 & 47 & 100 & 100 \\
\hline
\end{tabular}

Based on the table shows that of the 39 respondents who have good knowledge most consume herbal medicine as many as 28 respondents $(71.8 \%)$. Of the 51 respondents who have enough knowledge, most do not consume herbal medicine as many as 27 respondents $(52.9 \%)$. And of the 10 respondents who have less knowledge almost all do not consume herbal medicine as much as 9 respondents $(90 \%)$.

Based on the results of the chi square test obtained data value $\rho=0.007, \alpha=$ 0.05 so that $\rho=0.007<\alpha=0.05$ this means there is a relationship between knowledge and behavior in consuming herbal medicine.

Some research shows that informants have a positive perception of vulnerability about what herbs they think are susceptible to consumption if the contents are not yet known. This is because not all herbs can be freely consumed without knowledge, experience, information that supports the perception of informants. Research conducted by Dewi in 2015 on the knowledge of herbal medicine as a menstrual pain reliever in Klaten stated that $50 \%$ of respondents had a good knowledge of herbal medicine as a menstrual pain reliever, while in the Cloud study in 2014 not all respondents had a good perception of traditional herbal medicine. While research conducted by Romziyah in 2020 on the relationship of knowledge and public attitudes in using immunomodular herbs in efforts to prevent COVID-19 stated that there is no relationship between the level of knowledge and attitude of the community in efforts to prevent COVID-19 using immunomodular herbs. Another study related to the consumption of herbal medicine conducted by Adi in 2018 stated that a person's knowledge of something affects the person's practices or actions in this case is the relationship between knowledge to the practice of consumption of herbal medicine jun. 10

According to the assumptions of researchers, the results of this study show that most respondents already have a good enough knowledge about herbal medicine to maintain body health during the covid-19 period. Respondents' knowledge supports their actions or behavior in consuming herbal medicine, because with this knowledge respondents can better know and understand what herbs and how to consume them so that it is safe for them to consume in an effort to maintain health and improve immunity during the covid-19 pandemic. A person's knowledge has an important role in influencing a person's behavior or actions in consuming something or service. This shows that the better the knowledge about herbal medicine, the more routine a person will be in consuming herbal medicine to increase immunity during the covid-19 pandemic. 
2) Bivariate analysis between attitudes and behavior

Table 4. Cross-tabulation between attitude variables and herbal consumption behavior in Singaraja City

\begin{tabular}{lccccccc}
\hline \multirow{2}{*}{ Attitude } & \multicolumn{3}{c}{ Consumtion Behaviour } & \multirow{2}{*}{ Amount } \\
\cline { 2 - 5 } & \multicolumn{2}{c}{ Yes } & \multicolumn{2}{c}{ Not } & & \\
& $\mathrm{f}$ & $\%$ & $\mathrm{f}$ & $\%$ & f & $\%$ \\
\hline Negative & 16 & 35,6 & 29 & 64,4 & 45 & 100 \\
Positive & 37 & 67,3 & 18 & 32,7 & 55 & 100 \\
\hline Amount & 53 & 53 & 47 & 47 & 100 & 100 \\
\hline
\end{tabular}

Based on table 4 shows that of the 45 respondents who have a negative attitude most do not consume herbal medicine as many as 29 respondents $(45 \%$ and from 55 respondents who have a positive attitude mostly consume herbal medicine as many as 37 respondents $(67.3 \%)$.

The results of the chi square test showed that $\rho=0.001<\alpha=0.05$ then this means that there is a relationship between attitude and behavior in consuming herbal medicine.

Herbal medicine is a term for traditional medicine in Indonesia. Herbs are made from natural ingredients in the form of plants, animal body parts and spices. Herbal medicine as a traditional medicine plays an important role in the treatment of populations in developing countries. According to Wijisekera (1991) about 70-80\% of the population in developing countries has a dependence on traditional oabat or herbal medicine. The use of herbal medicine as an alternative to medicine in addition to modern medicine in the community is part of indigenous knowledge community9. The results of the Basic Health Research of the Ministry of Health of the Republic of Indonesia in 2018 on the use of herbal medicine by the people of Indonesia, found that $59.12 \%$ of the public still consume herbal medicine and more than $95.6 \%$ of the users recognize the benefits of herbal medicine for health. These results show that the knowledge and practice of public consumption in herbal medicine as a traditional medicine in Indonesia is still quite high. ${ }^{1}$

The results of this study showed that the attitudes possessed by respondents in this study is one of the things or aspects that affect the occurrence of a person's behavior. The attitude shown by respondents in this study illustrates how their response to traditional medicines such as herbal medicine can maintain body health during the covid-19 pandemic. The positive response or attitude will form a positive behavior towards the use of herbal medicine in maintaining body health. Negative respondent attitudes occur because respondents still consider that herbal medicine is not too safe to consume than medical drugs or other herbs, because herbal medicine has a greater negative effect or impact than other herbs. This shows that the more positive a person's attitude, the better and routine one will be in consuming herbal medicine. This research is in line with research conducted by Tiara et al (2019) proved that repsonden attitudes towards herbal drinking habits have a significant influence. ${ }^{18}$ 


\section{Journal Of Nursing Practice}

http://thejnp.org

3) Bivariate analysis between perception and behavior

Table 5. Cross-tabulation between perception variables and herbal consumption behavior in Singaraja City

\begin{tabular}{lccccccr}
\hline \multirow{2}{*}{ Perception } & \multicolumn{4}{c}{ Consumtion Behaviour } & \multicolumn{2}{c}{ Amount } \\
\cline { 2 - 5 } & \multicolumn{3}{c}{ Yes } & \multicolumn{2}{c}{ Not } & & \\
\cline { 2 - 6 } & $\mathrm{f}$ & $\%$ & $\mathrm{f}$ & $\%$ & $\mathrm{f}$ & $\%$ \\
\hline Negative & 15 & 36,6 & 26 & 63,4 & 41 & 100 \\
Positive & 38 & 64,4 & 21 & 35,6 & 59 & 100 \\
\hline Jumlah & 53 & 53 & 47 & 47 & 100 & 100 \\
\hline
\end{tabular}

Based on table 5 shows that of the 41 respondents who have negative perceptions most do not consume herbal medicine as many as 26 respondents $(63.4 \%)$ and of 59 respondents who have a positive perception mostly consume herbal medicine as many as 38 respondents (64.4\%).

The results of the chi square test showed that $\rho=0.006<\alpha=0.05$ then this means that there is a relationship between persepsu and behavior in consuming herbal medicine.

According to Puspitasari (2020) some herbal plants that have been studied and proven to be able to increase immunity include meniran (Phylanthus niruri), java chili (piper longum), lime (Citrus aurantifolia), turmeric (Curcuma longa). In addition, there are herbal processed as herbal medicine that is drunk directly, including rice kencur, turmeric asem, temulawak and traditional herbal drinks ${ }^{5}$. The behavior of the consumption of herbal medicine as a booster of the immune system is inseparable from the level of knowledge, attitude and perception of a person in the consumption of herbal medicine in the community.

According to the researchers, the results of this study show that the public still gives a positive response to traditional medicine through herbal medicine. This happens because the public already knows enough about the benefits of consuming herbal medicine that can maintain and increase immunity especially in the pandemic period this is needed. Therefore, many people still consider herbal medicine is one of the right alternatives in doing treatment or efforts to maintain health and improve immunity in the covid-19 pandemic. A person's perception is influenced by various factors such as objects, sensing, and attention, in addition to psychological, family and social cultural factors. This research is in line with the research conducted by Dewi, et al (2019) about the perception of mayarakat in the consumption of traditional medicine is safer because it is made from natural ingredients. ${ }^{20}$

4) Multivariate Analysis

Table 6. Multivariate Analysis between knowledge, attitude, perception with herbal consumption behavior in Singaraja City

\begin{tabular}{|c|c|c|c|c|}
\hline \multirow[t]{2}{*}{ Behaviour $^{\mathrm{a}}$} & & \multirow[t]{2}{*}{$\begin{array}{c}\operatorname{Exp}(B \\
\quad)\end{array}$} & \multicolumn{2}{|c|}{$\begin{array}{l}\text { 95\% Confidence } \\
\text { Interval for } \operatorname{Exp}(B)\end{array}$} \\
\hline & & & $\begin{array}{l}\text { Lower } \\
\text { Bound }\end{array}$ & $\begin{array}{l}\text { Upper } \\
\text { Bound }\end{array}$ \\
\hline \multirow[t]{3}{*}{ Consumption } & Intercept & & & \\
\hline & Knowledge & $\begin{array}{r}16.48 \\
3\end{array}$ & 1.793 & $\begin{array}{r}151.5 \\
51\end{array}$ \\
\hline & Attitude & 1.225 & .119 & 2.644 \\
\hline
\end{tabular}




\section{Journal Of Nursing Practice}

http://thejnp.org

ISSN: 2614-3488 (print); 2614-3496 (online)

Vol.5 No.1. October 2021. Page.94-102

\begin{tabular}{lrrr} 
perception & 1.652 & .138 & 19.79 \\
& & 7 \\
\hline
\end{tabular}

Based on table 6 above shows that knowledge variables have a higher chance of increasing the consumption of drinking herbal medicine than other variables with an OR (ExpB) value of 16,483 meaning that knowledge has a 16,483 times chance of influencing the behavior of consuming herbal medicine regularly.

The results of this study showed that respondents' knowledge of consuming herbal drinking affected respondents' behavior more than attitude and perception variables. Because with good knowledge will foster lasting behavior in consuming herbal medicine.

\section{CONCLUTION}

Most of the respondents' knowledge of traditional herbal medicine in the category is sufficient

Most attitudes towards traditional herbal medicine are in the positive category

Most of the respondents' behavior in the category of consuming herbal medicine during the covid-19 pandemic to maintain health

Some people's perceptions of traditional herbal medicine in katgeori positive

There is a relationship between knowledge and behavior in consuming herbal medicine during the covid-19 pandemic as evidenced by the results of the chisquare test which is $\rho=$ $0.007<\alpha=0.05$

There is a relationship between attitudes and behavior in consuming herbal medicine during the covid-19 pandemic as evidenced by the results of the chisquare test which is $\rho=0.001$ $<\alpha=0.05$

There is a relationship between perception and behavior in consuming herbal medicine during the covid-19 pandemic as evidenced by chisquare test results that are $\rho=0.006<\alpha$ $=0.05$

Knowledge is the dominant variable in influencing a person's behavior to consume herbal medicine regularly

\section{ACKNOWLEDGMENT}

The author is thankful to respondents in Singaraja City, Bali for their valuable information and their awareness to participate in this research

\section{REFERENCES}

1. Minister Of Healthy In Indonesia. (2018). Hasil Utama Riskesdas 2018.

2. Siswanto. (2012). Saintifikasi Jamu Sebagai Upaya Terobosan Untuk Mendapatkan Bukti Ilmiah Tentang Manfaat Dan Keamanan Jamu. Buletin Penelitian Sistem Kesehatan, 203-211.

3. PEMENKES 2010. Saintifikasi Jamu dalam Penelitian Berbasis Pelayanan Kesehatan. Peraturan Menteri Kesehatan Republik Indonesia Nomor :003/Menkes/Per/I/2010. Jakarta

4. Ersnt, M. H. C. \& J, S. Etichal Problems Arising in Evidence Based Complementary and Alternatif Medicine. Med Ethical 30, 56-59 (2004).

5. Puspitasari,Ika. 2020. Mengenal Herbal Pendongkrak Imun Tubuh. Universitas Gajah Mada. Artikel. 30 Maret 2020

6. Dinas Provinsi Bali. Jumlah Kasus Positif COVID-19 Provinsi Bali. 


\section{Journal Of Nursing Practice}

http://thejnp.org

https://infocorona.baliprov.go.id/ Akses 14 Oktober 2020

7. Sakri, F. (2012). 1001 Khasiat \& Manfaat Jamu Godog Untuk Segala Macam Penyakit. Yogyakarta: Diandra Pustaka Indonesia.

8. WHO 2005. Pemastian Mutu Obat Kompendium Pedoman dan Bahan-Bahan Terkait. EGC. Jakarta.

9. Wijisekera, R. (1991). Plant-derived Medicines And Their Role In Global Health. Florida: CRC Press

10. Pratama Adi. (2018) Pengetahuan dan Praktik Konsumsi Jamu Jun Pada Masyarakat Semarang. Indonesian Journal of Antropology III/2 76-84

11. Maharrani, A. (2018). Mempertahankan Eksistensi Jamu. Retrieved from Beritagar.id website: https://beritagar.id/artikel/gaya-hidup/mempertahankan-eksistensi-jamu

12. Dewi, Indri Kusuma, Yunianto, Bambang, 2015, Pengetahuan Tentang Jamu Sebagai Pereda Nyeri Haid Pada Siswi SMA N 1 Jatinom Klaten. Jurnal Kebidanan Indonesia vol 6 no. 2

13. Awan, Nita Adi, Wijayanti, Irfana Tri. 2014.Analisa Faktor Yang Berhubungan Konsumsi Jamu Tradisional Saat Menstruasi Dengan Dismenorhea Pada Wanita Usia Reproduksi Di Desa Glonggong Kecamatan Jakenan Kabupaten Pati. Jurnal Ilmu Kebidanan dan Kesehatan vol 5 (2) hal 20-25.

14. Pringgoutomo, S. (2007). Riwayat Perkembangan Pengobatan dengan Tanaman Obat di Dunia Timur dan Barat, Buku Ajar Kursus Herbal Dasar untuk Dokter. Jakarta: Balai Penerbit FKUI

15. Sudirga, S. K. (2012). Pemanfaatan Tumbuhan Sebagai Obat Tradisional Di Desa Trunyan Kecamatan Kintamani Kabupaten Bangli. Bumi Lestari Journal of Environment, 4(2)

16. Supardi, S., \& Susyanty, A. L. (2010). Penggunaan Obat Tradisional dalam Upaya Pengobatan Sendiri di Indonesia (Analisis Data SUSENAS Tahun 2007). Buletin Peneliti Kesehatan, 38(2), 80-89.

17. Sari, L. O. R. K. (2006). Pemanfaatan Obat Tradisional Dengan Pertimbangan Manfaat Dan Keamanannya. Majalah Ilmu Kefarmasian, III(1), 1-7.

18. Kusuma Mega. (2019) Hubungan Tingkat Pengetahuan dan Sikap Terhadap Kebiasan Konsumsi Jamu Pada Masyarakat Magelang. https://journals.ums.ac.id/index.php/pharmacon/article/view/10857/5728

19. Sinambela, D. P., Mahdiyah, D., dan Helmiah, R. (2016). Persepsi Remaja Puteri Tentang Konsumsi Jamu-jamuan Untuk Mengatasi Nyeri Haid di SMAN 8 Banjarmasin, Dinamika Kesehatan Volume 7 No.2

20. Dewi, R.S dkk (2019). Persepsi Masyarakat Mengenai Obat Tradisional Di Kelurahan Simpang Baru Kecamatan Tampan Kota Pekanbaru. Jurnal Penelitian Indonesia Vol. 8 No. 2 